\title{
Medium to long-term patterns of soil properties in forest restoration models in seasonally dry Atlantic Forest biome
}

Ranieri Ribeiro Paula ( $\nabla$ ranierirpaula@gmail.com )

INMA-MCTI Brazil https://orcid.org/0000-0002-2520-1779

\section{Research Article}

Keywords: Forest restoration, land uses, ecosystem services, soil fertility, soil organic carbon

Posted Date: January 27th, 2022

DOI: https://doi.org/10.21203/rs.3.rs-1300388/v1

License: (c) (i) This work is licensed under a Creative Commons Attribution 4.0 International License.

Read Full License 
1 Medium to long-term patterns of soil properties in forest restoration models in seasonally dry Atlantic Forest biome

3

Ranieri Ribeiro Paula ${ }^{1,2,3 *}$, Willian Macedo Delarmelina ${ }^{4}$, Luciana Lorenzoni-Pascoa ${ }^{1}$; Naiara

5

Machado Neves $^{1}$, Ítalo Favoretto Campanharo ${ }^{1}$, Julianne de Castro Oliveira ${ }^{5}$, Bruno Bordron ${ }^{6,7}$,

6 Marcos Vinícius W. Caldeira ${ }^{1}$, Marcos Gervasio Pereira ${ }^{8}$, Eduardo de Sá Mendonça ${ }^{2}$

7

$8{ }^{1}$ UFES, Departamento de Ciências Florestais e da Madeira, Av. Governador Carlos

9 Lindemberg, 316, Centro, Jerônimo Monteiro, Espírito Santo, CEP 29550-000, Brazil.

${ }^{2}$ UFES, Programa de Pós-Graduação em Produção Vegetal, Alto Universitário, s/n,

11 Guararema, Alegre, Espírito Santo, CEP 29500-000, Brazil.

$12{ }^{3}$ Instituto Nacional da Mata Atlântica (INMA-MCTI), Avenida José Ruschi (km 136),

13 Santa Teresa, Espírito Santo, CEP 29650-000, Brazil.

$14{ }^{4}$ IFES, Coordenadoria do Curso Técnico em Florestas, Av. 7 de novembro, 40, Centro, 15 Ibatiba, Espírito Santo, CEP 29395-000, Brazil.

$16{ }^{5}$ Faculdade de Engenharia Agrícola (FEAGRI), Av. Cândido Rondon, 501 - Cidade 17 Universitária, Campinas, São Paulo, CEP 13083-875, Brazil.

$18{ }^{6}$ Eco\&Sols, INRA, CIRAD, IRD, Montpellier SupAgro, University of Montpellier, 19 Montpellier, France.

${ }^{7}$ CIRAD, UMR Eco\&Sols, F-34398 Montpellier, France.

${ }^{8}$ UFRRJ, Departamento de Solos, BR 465 km 7, Seropédica, Rio de Janeiro, 23890-000, Brazil.

Email: ranierirpaula@gmail.com 


\section{HIGHLIGHTS}

- NF regenerated after coffee was the most depleted soil fertility and SOC storage

- Grass pasture and legume plantations showed smaller soil acidity and larger base concentration than NF areas

- SOC was large in NF regenerated after selective cutting and grass pasture

- Legume trees decreased SOC storage by $35 \%$ after planting on grass pasture

\section{ABSTRACT}

The medium- to long-term impacts of forest restoration models on soil properties are not well documented in the Atlantic Forest biome, especially in a seasonally dry climate. We assessed patterns of topsoil fertility, soil organic carbon (SOC) storage, and isotopic signatures of ${ }^{13} \mathrm{C}$ in gradient with three areas with natural regeneration of native forest (NF) with 50 years of old, two areas with monocultures of $\mathrm{N}_{2}$-fixer and non- $\mathrm{N}_{2}$-fixer tree species, six years after planting on grass pasture, and one area with grass pasture in the last 40 years of age. In each area, three to nine composite soil samples were collected at 0-20 cm soil depth during the rainy season for analysis. The topsoil of the NF regenerated after coffee was the most depleted soil fertility and SOC storage in our vegetation gradient. The grass pasture and forest plantations showed smaller soil acidity and a larger base concentrations than the NF areas. The SOC storage was larger in NF after grass pasture and selective cutting, followed by grass pasture, with 80,76 , and $69 \mathrm{Mg} \mathrm{ha}^{-1}$, respectively. The planting of legume trees decreased SOC storage by approximately $35 \%$ during SOC storage, independent of $\mathrm{N}_{2}$-fixing capacity. The SOC derived from trees increased rapidly in the first six years of tree plantation $\left(\approx 3 \mathrm{Mg} \mathrm{SOC} \mathrm{ha}^{-1}\right.$ year $\left.^{-1}\right)$. The 
recovery of soil fertility and SOC storage by long-term natural regeneration differs according to historical land use. Differences in $\mathrm{N}_{2}$-fixation capacity had little effect on soil properties in the medium term.

Keywords: Forest restoration, land uses, ecosystem services, soil fertility, soil organic carbon.

\section{INTRODUCTION}

The promotion of forest restoration and ecosystem services has been extensively debated in the Atlantic Forest biome of Brazil (Latawiec et al., 2015; Chazdon et al., 2017). This biome has the last 12 million hectares of abandoned land to be restored, and the other 15 million hectares of pasture (Chazdon et al., 2016). The planting of trees and natural regeneration are the two most used restoration interventions in the Atlantic Forest biome. The improvement of soil fertility and soil organic carbon (SOC) storage is one of the ecosystem services expected from the medium to long term after the restoration of agricultural lands. However, there are few field studies showing soil data for restorations with monocultures of native trees that have been established in the Atlantic Forest biome in the last decade (Mendes et al., 2019). In tropical regions, these concerns have mainly been evaluated for some tree genera, mainly Eucalyptus and Pinus, and $\mathrm{N}_{2}$-fixing trees such as Acacia, Albizia, Leucaena, and Casuarina genera (Marín-Spiotta and Sharma, 2013; Shi et al., 2016).

Soil carbon loss due to land-use change is the second major cause of the increasing $\mathrm{CO}_{2}$ in atmosphere after fossil fuels, and is mainly responsible for the increase in greenhouse gas emissions in tropical countries (Assad et al., 2013; Locatelli et al., 2015). Moreover, the conversion of land use affects several soil properties besides SOC (Guo 
and Gifford, 2002; Don et al., 2011), such as acidity, nitrogen, phosphorus, and cation exchange (Shi et al., 2016). In general, the pools of C, N, and other nutrients in natural forest soil (NF) are significantly reduced due to the conversion of NF to traditional agriculture, mainly with non-sustainable practices (Don et al., 2011; Lal, 2018). The conversion of NF to grass pasture has a controversial impact in the short to medium term (Guo and Gifford, 2002; Don et al., 2011). However, the recovery of soil properties often occurs when agriculture and grass pastures are restored by afforestation over the long term (Don et al., 2011). At the same time, there is an equal lake of soil data in natural forests regenerated after agriculture and grass pasture in the last half century, when it intensified the protection of native forests in Brazil (from 1964).

The effect of tree planting on soil fertility and SOC storage varies with previous use and management intensity (Laganière et al., 2010), and functional traits of the species (De Deyn et al., 2008). Positive effects on soil fertility and C status are often found when bare land and cropland are converted in tree plantations with stand age higher than 10-30 years (Guo and Gifford, 2002; Shi et al., 2016). However, the same patterns were less frequent when grass pastures were converted to tree plantations (Shi et al., 2016). Moreover, plantations using management practices with minimum soil interventions show higher SOC storage than plantations with high management intensity (Laganière et al., 2010). The $\mathrm{N}_{2}$-fixing legume tree species are an exception because several studies have shown a faster positive effect of these functional groups on soil properties when established in agricultural and grass pasture areas (Shi et al., 2016; Marín-Spiotta and Sharma 2013). However, few studies have been conducted to compare the effects of legume trees with different capacities to $\mathrm{N}_{2}$-fixation on soil properties after afforestation of grass pastures in the Atlantic Forest biome (Barroso et al., 2018). 
We carried out a field investigation to assess patterns of soil fertility (i.e., $\mathrm{pH}, \mathrm{Al}$,

$\mathrm{P}, \mathrm{K}, \mathrm{Ca}, \mathrm{Mg}$, base exchange), $\mathrm{C}$ and $\mathrm{N}$ concentrations, SOC storage, and isotopic signatures of ${ }^{13} \mathrm{C}$ in a gradient of vegetation localized in the seasonally dry Atlantic Forest biome in Southeast Brazil. The gradient of vegetation was composed of NF with at least 50 years of natural regeneration after selective logging, and after coffee agriculture or grass pasture, one grass pasture area with at least 40 years of age, and two monocultures with $\mathrm{N}_{2}$-fixing Anadenanthera peregrina var. peregrina (L.) Speg. and non- $\mathrm{N}_{2}$-fixing Schizolobium parahyba var. amazonicum (Huber \& Ducke) Barneby, six years after planting on grass pastures. Our hypotheses were as follows: 1) NF with at least 50 years of natural regeneration would show similar soil property patterns, and 2) the $\mathrm{N}_{2}$-fixing legume trees would improve soil properties by a major magnitude compared to non- $\mathrm{N}_{2}$ fixing legume trees.

\section{MATERIAL AND METHODS} over an area that describes a vegetation gradient ordinary to the Atlantic Forest biome of southeast Brazil. It involves the regeneration of NF, grass pastures, and tree plantations. The climate is classified as Aw, with rainy summers and dry winters. The mean annual rainfall is approximately $1200 \mathrm{~mm}$ with a dry period $(<50 \mathrm{~mm})$ from May to September, and the mean annual temperature is $23{ }^{\circ} \mathrm{C}$ (Alvares et al., 2013). The relief region varies from wavy to mountainous, with the occurrence of mountains and culvert chains and an average altitude of $150 \mathrm{~m}$ (IBGE, 1987). The slope ranged between $15 \%$ and $45 \%$ in most 
124 Bighi et al., 2021).
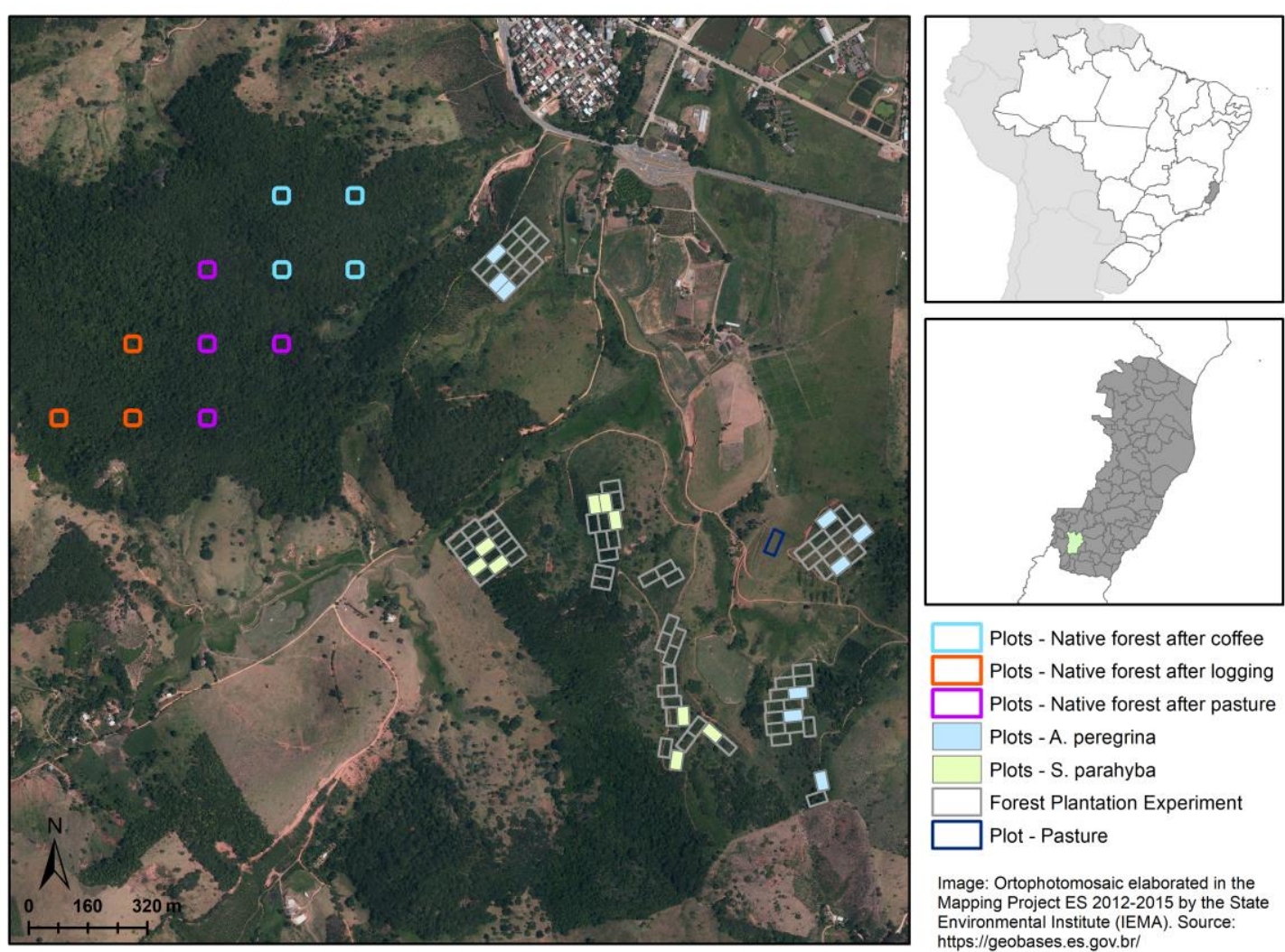

Plots - A. peregrina

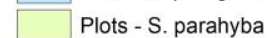

$\square$ Forest Plantation Experiment Plot - Pasture

Image: Ortophotomosaic elaborated in the Mapping Project ES 2012-2015 by the State Environmental Institute (IEMA). Source:
https://geobases.es.gov.br/

Fig. 1 Localization of plots in the vegetation gradient 109.6 hectares. The fragment was previously subjected to three different disturbances: coffee plantations, African grass pasture, and selective tree cutting (Lorenzoni-Paschoa et al., 2019). This previous land use and management occurred at least 50 years ago. The fragments contained a minimum of 153 identified tree species. However, the main tree species were Pseudopiptadenia contorta, Parapiptadenia pterosperm, and Apuleia 
no statistically significant difference between previous land use and management 137 (Lorenzoni-Paschoa et al., 2019).

The plantation of A. peregrina trees and S. parahyba trees was established in areas managed with grass pastures for more than 40 years with Brachiaria sp. dominant species.

140 We used data from nine of these experimental plots per species planted in 2011 with a 3 $\mathrm{m} \times 3 \mathrm{~m}$ tree spacing (stand density of 1111 trees ha $^{-1}$ ) (Bighi et al., 2021). The seedlings were produced from seeds originating from stock plants located in Dom Elizeu, state of Pará, Brazil, in Reserva Natural Vale in Linhares, state of Espirito Santo (Instituto Ambiental Vale). The seedlings of A. peregrina were not inoculated with rhizobial strains. However, natural nodules were observed in the study area (Mendes et al., 2021). The cattle were removed before planting, and the pasture was desiccated by applying glyphosate. The seedlings were planted in pits with dimensions of $30 \mathrm{~cm} \times 30 \mathrm{~cm} \times 30$ $\mathrm{cm}$. Each seedling received $220 \mathrm{~g}$ of commercial fertilizer (NPK 06-30-06) more of leaf cutter ants. occurred in the first 12 months after planting, with replanting, crowning, and the control

\section{Soil sampling}

For the regenerated NF, the soil data determined by Lorenzoni-Paschoa (2016) and Neves (2018) at the 0-20 cm soil layer in 11 permanent plots were used. Each plot had an area of $400 \mathrm{~m}^{2}(20 \mathrm{~m} \times 20 \mathrm{~m})$. Four plots were localized in the zones with NF regenerated after grass pasture and agriculture (coffee), and three plots were localized in the zone with the selective cutting of trees (Fig. 1). During the rainy season of 2015, ten soil samples per plot were collected and mixed in one soil sample. Soil fertility and texture were assessed in this study (Lorenzoni-Paschoa, 2016). Soil N and C concentrations and SOC 
storage were determined in the rainy season of 2018 from five simple soil samples collected per plot and mixed (Neves, 2018). Soil density was also measured at two points per plot, using a metal ring with a volume of $106.7 \mathrm{~cm}^{3}$ (Neves, 2018). Finally, the same soil samples collected by Neves (2018) were used to determine the natural abundance of ${ }^{13} \mathrm{C}$ in each plot.

For the grass pasture area, soil samples collected in the $0-20 \mathrm{~cm}$ layer on two occasions were used. Soil fertility and soil density were determined in soil samples collected from grass pasture areas during the rainy season of 2010, 12 months before tree plantation (Campanharo, 2017). On this occasion, 360 simple samples distributed systematically in all areas with tree plantations were collected (Fig. 1). The samples were mixed into six composite samples for the fertility analysis. Soil density was measured in 60 samples distributed systematically in all areas used for planting tree legumes. For $\mathrm{N}$ and $\mathrm{C}$ concentrations, natural abundance of ${ }^{13} \mathrm{C}$, and texture, one area with grass pasture soil samples were mixed in one composite sample per plot and used for fertility analysis. The soil density was determined using a $5 \mathrm{~cm}$ diameter metal ring in a single sample 
SOC storage, isotopic composition of ${ }^{13} \mathrm{C}$, and soil texture were determined using soil samples collected by Campanharo (2017).

\section{Laboratory analysis}

All analyses of soil fertility, soil density, and soil texture were carried out according to Embrapa (1997). The soil samples for soil density assessment were weighed on a precision balance after drying at $105{ }^{\circ} \mathrm{C}$ for $72 \mathrm{~h}$. The proportions of clay, silt, and sand were determined using a pipetting method. The soil samples used for chemical analysis were air-dried, macerated, and sieved $(0.5 \mathrm{~mm}) . \mathrm{pH}_{\mathrm{H} 2 \mathrm{O}}$ was determined to be 1:2.5. Phosphorus (P) and potassium (K) were extracted using Melich 1. Exchangeable $\mathrm{Al}, \mathrm{Ca}$, and $\mathrm{Mg}$ were extracted using $\mathrm{KCl}\left(1 \mathrm{~mol} \mathrm{~L}^{-1}\right)$.

Soil $\mathrm{N}$ concentration was determined according to the Kjeldahl method (Mendonça and Matos, 2005). Soil $\mathrm{C}$ concentration and $\delta^{13} \mathrm{C}$ were determined using a 20-20 Hydra mass spectrometer (ANCA-GSL, SERCON Co., Crewe, Uk) (Boutton, 1991). The $\delta^{13} C_{\text {VPDB }}$ signature (i.e., using the Vienna Pee Dee Belemnite standard) was calculated.

\section{Data analysis}

The SOC storage $\left(\mathrm{Mg} \mathrm{ha}^{-1}\right)$ at $0-20 \mathrm{~cm}$ was estimated using the soil $\mathrm{C}$ concentration (\%) multiplied by the soil mass measured in each vegetation.

The amounts of SOC derived from trees and grass were calculated by multiplying the SOC storage by the proportion of $\mathrm{C}$ derived from each vegetation. The proportion of SOC derived from trees and grass was estimated using Equations 1 and 2, respectively:

$$
\% \text { trees }=\left(\frac{\delta \text { soil tree }-\delta \text { soil pasture }}{\delta \text { soil ref }-\delta \text { soil pasture }}\right) * 100
$$


209 Where: $\% \mathrm{C}$ trees or $\% \mathrm{C}$ grass is the proportion of SOC derived from trees and grass; $\delta$ 210 is the $\delta^{13} \mathrm{C}(\%)$ value determined in each plot by tree plantation $(\mathrm{N}=9)$, and in each plot 211 with $\mathrm{NF}$ regenerated after pasture $(\mathrm{N}=4) ; \delta$ soil pasture is the mean value of $\delta^{13} \mathrm{C}(\%)$ in

212 soil sampled in pasture area; and $\delta$ soil ref is the mean value of $\delta^{13} \mathrm{C}(\%)$ in soil sampled in $\mathrm{NF}$ regenerated after selective cutting $(\mathrm{N}=3)$.

The mean values of the chemical and physical properties of the soil were compared among areas using one-way ANOVA for normal data or the Kruskal-Wallis test for non-normal data. The mean values of soil properties in each of the five areas were compared with the control group NF after selective cutting using Dunnett's method for normal data, or Dunn's method for non-normal data. Normality was tested using the Shapiro-Wilk test. Statistical analysis was performed with SigmaPlot 13 (Systat, 2014), using a statistical threshold value of $\mathrm{P}=0.05$.

\section{RESULTS}

There were different patterns of soil fertility among the areas in the studied vegetation gradient (Tab. 1). Soil acidity and $\mathrm{Al}$ concentration were higher mainly in the regenerated coffee than in the grass pasture or legume plantations. The mean $\mathrm{P}$ concentrations were generally larger in legume tree plantations, but the difference was 227 not statistically significant. The base concentrations were often smaller in the NF-coffee culture than in the other areas. In addition, the base concentrations were often larger in grass pasture and legume tree plantations than in NF areas. However, statistical differences among the areas were found only for $\mathrm{Mg}$ concentrations. 

equal among the areas (Tab. 1). In contrast, the C concentration was larger in NF-SC and NF-grass, followed by grass pastures. At the same time, the $\mathrm{C}$ concentrations were similar 234 in legume trees and NF-coffee plantations. The $\mathrm{C}$ concentration was 1.6 time higher in 235 the reference area NF-SC than in the tree plantation and NF-coffee. The $\delta^{13} \mathrm{C}$ values were statistically higher in grass pasture and tree plantation areas than in the reference NF-SC. $\delta^{13} \mathrm{C}$ assumed intermediate values between NF and grass pastures. soil texture was statistically equal among areas, with clay concentrations ranging from $50 \%$ to $56 \%$, and sand concentrations from $35 \%$ to $42 \%$.

The SOC storage values were 1.7 times higher in NF-SC, NF-grass, and grass time, the SOC storage was similar among the NF-coffee and legume tree plantations, with mean values ranging from 41 to $44 \mathrm{Mg} \mathrm{ha}^{-1}$. in NF-grass. In addition, the SOC derived from the tree was slightly larger in S. parahyba than in A. peregrina, with 19 and $15 \mathrm{Mg} \mathrm{ha}^{-1}$, respectively. Furthermore, the SOC derived plantations and $2 \mathrm{Mg} \mathrm{ha}^{-1}$ in NF-grass. 


\begin{tabular}{|c|c|c|c|c|c|c|}
\hline \multirow[b]{2}{*}{ Variables } & \multicolumn{6}{|c|}{ Vegetational gradient } \\
\hline & NF - SC & NF - grass & NF - coffee & Grass pasture & S. parayba & A. peregrina \\
\hline $\mathrm{pH}$ (water) * & $5.15 \pm 0.70$ & $5.18 \pm 0.63$ & $4.46 \pm 0.13$ & $5.74 \pm 0.33$ & $5.45 \pm 0.53$ & $5.33 \pm 0.19$ \\
\hline $\mathrm{Al}\left(\mathrm{cmol}_{\mathrm{c}} \mathrm{dm}^{-3}\right) *$ & $0.29 \pm 0.44$ & $0.30 \pm 0.22$ & $0.78 \pm 0.28 \dagger$ & $0.09 \pm 0.12$ & $0.09 \pm 0.12$ & $0.06 \pm 0.04$ \\
\hline $\mathrm{P}\left(\mathrm{cmol}_{\mathrm{c}} \mathrm{dm}^{-3}\right)$ & $1.55 \pm 0.47$ & $2.23 \pm 0.31$ & $1.80 \pm 0.41$ & $2.00 \pm 0.40$ & $2.71 \pm 0.78$ & $2.79 \pm 2.41$ \\
\hline $\mathrm{K}\left(\mathrm{cmol}_{\mathrm{c}} \mathrm{dm}^{-3}\right)$ & $92.77 \pm 41.71$ & $101.03 \pm 33.04$ & $44.83 \pm 13.82$ & $72.46 \pm 18.65$ & $69.67 \pm 38.40$ & $53.33 \pm 24.27$ \\
\hline $\mathrm{Ca}\left(\mathrm{cmol}_{\mathrm{c}} \mathrm{dm}^{-3}\right)$ & $1.72 \pm 1.09$ & $1.95 \pm 1.46$ & $0.47 \pm 0.47$ & $2.44 \pm 1.37$ & $2.52 \pm 2.03$ & $3.07 \pm 2.04$ \\
\hline $\operatorname{Mg}\left(\mathrm{cmol}_{\mathrm{c}} \mathrm{dm}^{-3}\right) *$ & $1.16 \pm 0.35$ & $1.21 \pm 0.38$ & $0.66 \pm 0.24$ & $1.51 \pm 0.66$ & $1.33 \pm 0.81$ & $2.21 \pm 1.11$ \\
\hline $\mathrm{CEC}\left(\mathrm{cmol}_{\mathrm{c}} \mathrm{dm}^{-3}\right)$ & $3.43 \pm 1.15$ & $3.73 \pm 1.69$ & $2.04 \pm 0.47$ & $4.23 \pm 1.91$ & $4.14 \pm 2.68$ & $5.49 \pm 3.14$ \\
\hline $\mathrm{C}(\%) *$ & $2.74 \pm 0.26$ & $2.88 \pm 1.04$ & $1.70 \pm 0.53 \dagger$ & $2.28 \pm 0.25$ & $1.75 \pm 0.30 \dagger$ & $1.80 \pm 0.31 \dagger$ \\
\hline $\mathrm{N}(\%)$ & $0.21 \pm 0.07$ & $0.20 \pm 0.05$ & $0.25 \pm 0.07$ & $0.21 \pm 0.04$ & $0.19 \pm 0.05$ & $0.20 \pm 0.03$ \\
\hline$\delta^{13} \mathrm{C}(\delta \%)^{*}$ & $-26.16 \pm 0.45$ & $-25.88 \pm 0.46$ & $-26.43 \pm 0.38$ & $-16.75 \pm 0.27 \dagger$ & $-20.33 \pm 1.40 \dagger$ & $-19.59 \pm 1.30 \dagger$ \\
\hline Density $\left(\mathrm{g} \mathrm{cm}^{-3}\right) *$ & $1.39 \pm 0.03$ & $1.37 \pm 0.14$ & $1.21 \pm 0.04$ & $1.51 \pm 0.04$ & $1.28 \pm 0.11$ & $1.24 \pm 0.06$ \\
\hline Clay (\%) & $54.85 \pm 2.77$ & $55.13 \pm 5.54$ & $49.76 \pm 3.89$ & $52.88 \pm 20.09$ & $51.46 \pm 8.33$ & $56.46 \pm 4.45$ \\
\hline Sand $(\%)$ & $37.10 \pm 3.78$ & $35.99 \pm 2.62$ & $42.18 \pm 4.98$ & $40.98 \pm 12.62$ & $39.73 \pm 4.69$ & $35.15 \pm 6.31$ \\
\hline
\end{tabular}




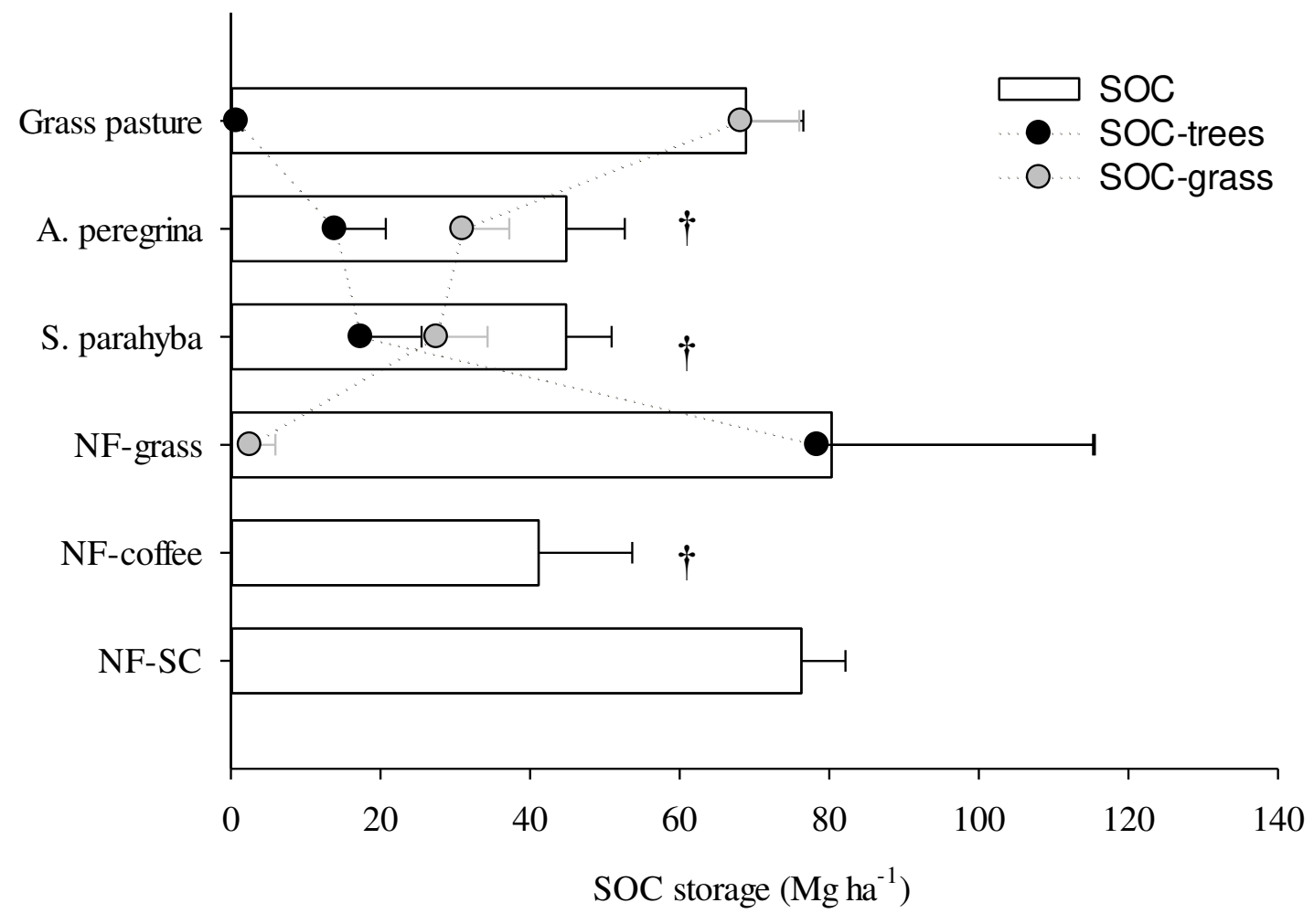

Fig. 2 Mean values of SOC storage ( \pm standard deviation) at $0-20$ soil layer in vegetational gradient compose by native forest (NF) regenerate after the selective cutting 257 of trees (SC), grass pasture (grass), agriculture (coffee), and in grass pasture, and legume tree species plantations. The amounts of SOC derived from trees (black) and grass (grey) plants area showed by scattering lines. $\dagger$ Difference significant between each area and control NF-SC

DISCUSSION

The topsoil of NF regenerated after coffee culture was depleted in most soil properties compared to other NF after selective cutting and grass pasture. In fact, the soil acidity, Al, and base concentrations in the NF-coffee area were the lowest soil fertility class of soil fertility for the Espírito Santo state (Prezotti et al., 2007). In contrast, NF regenerated after grass pasture showed similar patterns of soil fertility and $\mathrm{C}$ pools 
compared to the NF after selective cutting. Guo and Gifford (2002) showed that the replacement of natural forests by agriculture was responsible for the reduction of $\mathrm{C}$ stocks by up to $60 \%$ in the first $30 \mathrm{~cm}$ of depth. However, the authors found that the conversion of natural forests to grass pastures does not result in a reduction in the $\mathrm{C}$ stock in regions with annual rainfall ranging from to $1000-3000 \mathrm{~mm}$. NF regenerated after coffee and grass pasture areas, in addition to natural soil variability.

The conversion of land use from NF to agriculture and livestock is achieved by harvesting all valuable wood species followed by the burning of forest slash. The traditional management of coffee culture, where the plants are alone, favors the loss of SOC and soil nutrients (Sales et al., 2013), especially in the early ages due to little ground cover. In addition, coffee plants were likely unfertilized in the 1960s. Grass pastures are widely known for their ability to store organic matter in soil Abdalla et al. (2018). The lower values of SOC storage in grass pasture area than in NF after selective cutting could be caused by occasional burning in the past of the seasonally dry Atlantic Forest. Although specific information about the historical burning in these areas is unknown, burning is a common practice used in agriculture and grass pastures in the region of study (Gobbo et al., 2016). Finally, we observed great stand deviation in SOC storage in the NF after the grass area. This was caused by one plot that showed high SOC storage (119 $\left.\mathrm{Mg} \mathrm{ha}^{-1}\right)$ and CEC concentration $\left(6.24 \mathrm{cmol}_{\mathrm{c}} \mathrm{dm}^{-3}\right)$ in the gradient. This plot had the lowest altitude and the slope of the NF area. The CEC concentration found in this plot was the highest among soil fertility classes in the Espírito Santo state (Prezotti et al., 2007). Thus, we noticed the removal of this plot of the calculations, and the mean SOC storage values for NF after grass were reduced to $67 \pm 13 \mathrm{Mg} \mathrm{ha}^{-1}$. This value is very similar to that observed for 
grass pasture areas. The CEC value in the other three plots of NF after grass area was 2.89 $\mathrm{cmol}_{\mathrm{c}} \mathrm{dm}^{-3}$.

The soil impact of coffee culture could be observed in the long term in the seasonally dry Atlantic Forest region. Although natural regeneration faced a more stressful soil environment in the coffee area than in the grass pasture area, the basal area of the stand was statistically equal between NF areas (Lorenzoni-Paschoa et al., 2019). Moreover, litterfall production and N, P, and C inputs were very similar among the NF areas (Neves, 2018, unpublished data). Thus, the availability of nutrients in the soil likely has less effect on the long-term accumulation of biomass after 50 years. However, differences in the structure and phytosociology of vegetation between NFs have been observed (Lorenzoni-Paschoa et al., 2019). These authors found similar species richness and diversity between NFs regenerated after selective cutting of the tree and after grass. At the same time, the pattern difference in NF after coffee showed slower advancement of the successional stage of vegetation in this area than in NF after grass (LorenzoniPaschoa et al., 2019).

Further studies could assess more details of soil type and parental material to confirm the tendencies in NF areas. Paz et al. (2016) showed that clay-rich soils have higher SOC storage than sandy-rich soils. However, in sandy soils, there was an increase in SOC storage over the time of forest succession. On the other hand, the slow recovery of SOC storage in NF regenerated after coffee may be explained by the high clay content in the topsoil layer. Moreover, the area with NF regenerated after grass pasture still presents recalcitrant forms of grass-derived C, possibly protected in macroaggregates (Six et al., 2002). 
$20 \mathrm{~cm}$ layer in relation to pasture area at six years after planting. This difference in SOC storage is between the highest observed in reviews and meta-analyses (Guo and Gifford, 2002; Don et al., 2011; Shi et al., 2016). Mass correction (Don et al., 2011) was not used to minimize the effects of land use on topsoil density because of small differences in patterns observed for SOC storage. Using the correction of soil mass with native forest after selective logging as a reference por example, the estimated decrease in SOC by legume tree planting on grass pasture was $22 \%$. However, we showed that the patterns are different for $\mathrm{N}_{2}$-fixing tree species because, in general, there is an increase in SOC storage after the establishment of this species (Guo and Gifford, 2002; Shi et al., 2016). Moreover, the change in the isotopic composition of ${ }^{13} \mathrm{C}$ suggested a faster loss of labile soil $\mathrm{C}$ derived from grass in the first six years after planting. At the same time, the input of SOC derived from trees was slightly higher in S. parahyba than in A. peregrina trees (2021). than in A. peregrina. Plots with S. parahyaba were completely occupied by Brachiaria values in the soil with $S$. parahyba than in A. peregrina trees. This pattern may be explained by the functional traits of trees that influence the litter decomposition process 
and SOC in S. parahyba. For example, the $\delta^{13} \mathrm{C}$ value was smaller in the leaf litter of $S$. parahyba than in A. peregrina (Paula et al., unpublished data). Furthermore, it is likely that SOC derived from both legume trees occurred in the sand fraction because of the significant negative correlation by Spearman correlation between clay content and SOC derived from trees $(-0.523 ; \mathrm{P}=0.0255 ; \mathrm{N}=18)$. Further studies should assess more details about the litter quality of this legume species, as well as the correlations between texture and SOC derived from species over the long term in this planting. pasture areas, although the differences were not statistically significant. These results may also be explained by the effect of fertilizer in the planting, which has been cycled by trees over the years. However, the differences in chemical properties, although subtle, indicate that soil fertility (e.g., CEC) was likely affected by the $\mathrm{N}_{2}$-fixer trees compared to $S$. parahyba, but not by $\mathrm{N}$ and $\mathrm{C}$ pools. Faster improvement in soil fertility occurs with the introduction of fast-growing $\mathrm{N}_{2}$-fixing trees, mainly on severely degraded land in the Atlantic Forest biome Macedo et al. (2008). However, this does not appear to have been the case for our grass pasture, since soil fertility parameters were similar or greater in the grass pasture than in the NF.

\section{CONCLUSION}

models with long-term natural regeneration areas and medium-term legume tree plantations. Fifty years after traditional coffee culture, the $0-20 \mathrm{~cm}$ soil depth still showed higher soil acidity and lower soil fertility parameters, as well as SOC storage, while soil properties were more similar between NF after grass pasture and selective cutting. Thus, the patterns of topsoil properties suggest that long-term natural regeneration may be 
insufficient to recover the original topsoil in previous coffee areas of seasonally dry tropical climates. However, further studies are needed to assess more soil and land historical details to confirm our results. Legume tree plantations established on grass pasture showed similar trends of decrease in approximately $35 \%$ of the SOC storage compared to grass pasture area. However, the SOC derived from trees increased rapidly in the first six years of tree plantation $\left(\approx 3 \mathrm{Mg} \mathrm{SOC} \mathrm{ha}^{-1}\right.$ year $\left.^{-1}\right)$. Furthermore, the differences in soil fertility suggested a more positive effect of $\mathrm{N}_{2}$-fixer $A$. peregrina than non- $\mathrm{N}_{2}$-fixer $S$. parahyba, although statistically significant differences were not found up to six years after planting.

\section{ACKNOWLEDGEMENT}

We would like to thank Conselho Nacional de Desenvolvimento Científico e Tecnológico - $\mathrm{CNPq}$ - for the financial support (Post-Doc fellowships numbers 300369/2016-6 and 159972/2018-3) and Fundação de Amparo à Pesquisa e Inovação do Espírito Santo (grants 71416382/2016 and 64946088/2013). We are also grateful for

Estáveis of CENA/USP for their technical support. We would like to thank Instituto

Federal de Ciência e Tecnologia do Espírito Santo, Campus de Alegre, and your partners, for the available study area formally called the "Floresta Piloto" and "Polo Educação Ambiental da Mata Atlântica".

\section{REFERENCE}

ABDALLA, M.; HASTINGS, A.; CHADWICK, D. R. R.; et al. Critical review of the impacts of grazing intensity on soil organic carbon storage and other soil quality indicators in extensively managed grasslands. Agriculture, Ecosystems and 
Environment, v. 253, p. 62-81, 2018.

ALVARES, C. A.; STAPE, J. L.; SENTELHAS, P. C.; DE MORAES GONÇALVES, J. L.; SPAROVEK, G. Köppen's climate classification map for Brazil. Meteorologische Zeitschrift, v. 22, n. 6, p. 711-728, 2013.

ASSAD, E. D.; PINTO, H. S.; MARTINS, S. C.; et al. Changes in soil carbon stocks in Brazil due to land use: Paired site comparisons and a regional pasture soil survey. Biogeosciences, v. 10, n. 10, p. 6141-6160, 2013.

BARROSO, D. G.; SOUZA, M. G. O. DA S.; OLIVEIRA, T. P. DE F. DE;

SIQUEIRA, D. P. Growth of atlantic forest trees and their influence on topsoil fertility in the southeastern brazil. CERNE, v. 24, n. 4, p. 352-359, 2018.

BIGHI, K. N.; PAULA, R. R.; CALDEIRA, M. V. W.; et al. Nitrogen Pools in Tropical Plantations of $\mathrm{N}_{2}$-fixing and non- $\mathrm{N}_{2}$-fixing legume trees under different tree stand densities. Nitrogen, v. 2, n. 1, p. 86-98, 2021.

CAMPANHARO, I.F. Mudanças edáficas após plantio de leguminosas arbóreas em pastagem no sul do Espírito Santo. Monograph, Federal University of Espírito Santo, Jerônimo Monteiro. 2017.

CHAZDON, R. L.; BRANCALION, P. H. S.; LAMB, D.; et al. A Policy-Driven Knowledge Agenda for Global Forest and Landscape Restoration. Conservation Letters, v. 10, n. 1, p. 125-132, 2017.

CHAZDON, R. L.; BROADBENT, E. N.; ROZENDAAL, D. M. A.; et al. Carbon sequestration potential of second-growth forest regeneration in the Latin American tropics. Science Advances, v. 2, n. 5, 2016.

DE DEYN, G. B.; CORNELISSEN, J. H. C.; BARDGETT, R. D. Plant functional traits and soil carbon sequestration in contrasting biomes. Ecology Letters, v. 11, n. 5, p. 516- 
$531,2008$.

414

DON, A.; SCHUMACHER, J.; FREIBAUER, A. Impact of tropical land-use change on

415

soil organic carbon stocks - a meta-analysis. Global Change Biology, v. 17, n. 4, p.

416 1658-1670, 2011.

417 Empresa Brasileira de Pesquisa Agropecuária (EMBRAPA). Manual de

418 métodos de análise de solos (2. ed). Rio de Janeiro: Embrapa Solos. 1997. 230 p.

419

GOBBO, S. D. ANGEL. A.; GARCIA, R. F.; DO AMARAL, A. A.; et al. Uso da terra

420

no entorno do PARNA-Caparaó: Preocupação com Incêndios florestais. Floresta e

421

Ambiente, v. 23, n. 3, p. 350-361, 2016.

422 GUO, L. B.; GIFFORD, R. M. Soil carbon stocks and land use change: a meta analysis.

423 Global Change Biology, v. 8, n. 4, p. 345-360, 2002.

424

Instituto Brasileiro de Geografia e Estatística (IBGE) Projeto RADAM, Folha SE 24

425

Rio Doce, Rio de Janeiro. 1987.

426

LAGANIÈRE, J.; ANGERS, D. A.; PARÉ, D. Carbon accumulation in agricultural

427 soils after afforestation: A meta-analysis. Global Change Biology, v. 16, n. 1, p. 439-

$428 \quad 453,2010$.

429

LAL, R. Digging deeper: A holistic perspective of factors affecting soil organic carbon

430 sequestration in agroecosystems. Global Change Biology, v. 24, n. 8, p. 3285-3301,

431 2018 .

432

LATAWIEC, A. E.; STRASSBURG, B. B. N.; BRANCALION, P. H. S.;

433

RODRIGUES, R. R.; GARDNER, T. Creating space for large-scale restoration in

434 tropical agricultural landscapes. Frontiers in Ecology and the Environment, v. 13, n. 4,

435 p. 211-218, 2015.

436

LOCATELLI, B.; CATTERALL, C. P.; IMBACH, P.; et al. Tropical reforestation and 
437

438

439

440

441

442

443

444

445

446

447

448

449

450

451

452

453

454

455

456

457

458

459

460

climate change: Beyond carbon. Restoration Ecology, v. 23, n. 4, p. 337-343, 2015.

LORENZONI-PASCHOA, L. de S.; ABREU, K. M. P. de; SILVA, G. F. da; et al.

Estágio sucessional de uma floresta estacional semidecidual secundária com distintos

históricos de uso do solo no sul do Espírito Santo. Rodriguésia, v. 70, 2019.

LORENZONI-PASCHOA, L. de S. Indicadores de estágio sucessional em um

fragmento florestal de mata atlântica no sul do Espírito Santo. Master dissertation.

Federal University of Espirito Santo. 2016.

MACEDO, M. O.; RESENDE, A. S.; GARCIA, P. C.; et al. Changes in soil C and N

stocks and nutrient dynamics 13 years after recovery of degraded land using leguminous

nitrogen-fixing trees. Forest Ecology and Management, v. 255, n. 5-6, p. 1516-1524, 2008 .

MARÍN-SPIOTTA, E.; SHARMA, S. Carbon storage in successional and plantation forest soils: A tropical analysis. Global Ecology and Biogeography, v. 22, n. 1, p. 105117, 2013.

MENDES, L. J.; PAULA, R. R.; DE SOUZA, P. H.; et al. Nitrogen accumulated and biologically fixed by uninoculated Anadenanthera peregrina (L.) Speg trees under monospecific stands in the Atlantic Forest biome. Brazilian Journal of Botany, v. 44, n. 2, p. 503-512, 2021.

MENDES, M. S.; LATAWIEC, A. E.; SANSEVERO, J. B. B.; et al. Look down-there is a gap - the need to include soil data in Atlantic Forest restoration. Restoration Ecology, v. 27, n. 2, p. 361-370, 2019.

Neves, N.M. Regeneração natural e ciclagem de nutrientes em fragmento de Floresta Estacional dominado por Fabaceae em Alegre, ES. Master dissertation. Federal University of Espirito Santo. 2018. 
PAZ, C. P.; GOOSEM, M.; BIRD, M.; et al. Soil types influence predictions of soil

462

463

464

465

466

467

468

469

470

471

472

473

474

475

476

477

478

479

carbon stock recovery in tropical secondary forests. Forest Ecology and Management, v. 376, p. 74-83, 2016.

PREZOTTI, L.C.; GOMES, J.A.; DADALTO, G.G.; OLIVEIRA, J.A. Manual de Recomendação de Calagem e Adubação para o Estado do Espírito Santo (5 Ed).Vitória: SEEA/INCAPER/CEDAGRO. 2007. 305 p.

SALES, E. F.; ERNESTO MÉNDEZ, V.; CAPORAL, F. R.; FARIA, J. C.

Agroecological transition of conilon coffee (Coffea canephora) agroforestry systems in the State of Espírito Santo, Brazil. Agroecology and Sustainable Food Systems, v. 37, n. 4, p. 405-429, 2013.

SHI, S.; PENG, C.; WANG, M.; et al. A global meta-analysis of changes in soil carbon, nitrogen, phosphorus and sulfur, and stoichiometric shifts after forestation. Plant and Soil, v. 407, n. 1-2, p. 323-340, 2016.

SIX, J.; CONANT, R. T.; PAUL, E. A.; PAUSTIAN, K. Stabilization mechanisms of soil organic matter: Implications for C-saturation of soils. Plant and Soil, v. 241, n. 2, p. 155-176, 2002.

Systat Software Inc. SigmaPlot for windows, Version 13.0. Registration number: 775302386. 2014. 